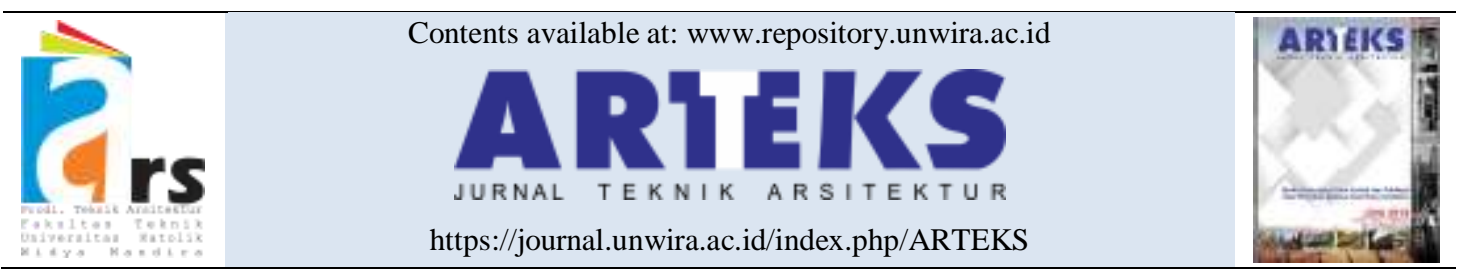

Research paper

doi: 10.30822/arteks.v6i2.701

\title{
The effect of the furniture industry towards the layout pattern of business house space in the Jorongan Village, Probolinggo
}

\author{
Adita Ronarizkia ${ }^{\circledR}$, Lisa Dwi Wulandari ${ }^{\circledR}$, Yusfan Adeputera Yusran* \\ Master Program of Architecture and Built Environment, \\ Department of Architecture, Universitas Brawijaya \\ Jl. MT. Haryono, no. 167, Malang, Indonesia

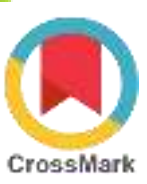

\begin{tabular}{|c|c|}
\hline ARTICLE INFO & ABSTRACT \\
\hline $\begin{array}{l}\text { Article history: } \\
\text { Received October } 16,2020 \\
\text { Received in revised form Nov. } 23,2020 \\
\text { Accepted November } 29,2020 \\
\text { Available online August } 01,2021 \\
\end{array}$ & $\begin{array}{l}\text { Jorongan Village is as an area designated as the Furniture Industry } \\
\text { Center of Probolingggo Regency, thereby leading to changes in } \\
\text { some houses functionality from residential to business. This } \\
\text { certainly changes the internal and external layout of the houses used } \\
\text { for furniture business. The purpose of this research is to identify the }\end{array}$ \\
\hline $\begin{array}{l}\text { *Corresponding author: Yusfan Adeputera } \\
\text { Yusran } \\
\text { Department of Architecture, Universitas } \\
\text { Brawijaya, Indonesia } \\
\text { Email: yusfan@ub.ac.id } \\
\text { ORCID: https://orcid.org/0000-0002-2082- } \\
9153\end{array}$ & $\begin{array}{l}\text { spatial layout pattern of business houses in the furniture industrial } \\
\text { center area of Probolinggo Regency. This research was carried out } \\
\text { with the behavior mapping approach used to describe the existing } \\
\text { space in each furniture business house. Therefore, based on the } \\
\text { analysis results, there are four patterns of business function space } \\
\text { layout, the first, second, and third are located at the front, side and } \\
\text { partially inside the building, while the other part is located in the } \\
\text { side. Furthermore, the pattern with part of the business function } \\
\text { space is located inside the building, and partly outside the front and } \\
\text { side of the house. The result showed that three houses had irregular } \\
\text { patterns with different layouts from other businesses. }\end{array}$ \\
\hline
\end{tabular}

\section{Introduction}

One of the Indonesian government foundations used to enhance the country's economy is by creating small and medium-sized enterprises (SME) (Lestari 2010). The SME role in helping a country to improve its economy, is by increasing export products. According to Siswaningsih (2016), one of the leading Indonesian products that can be developed to become the main export commodity is wooden furniture. Small and medium industries in Indonesia are mostly homebased businesses (id: Usaha Berbasis Rumah Tangga (UBR)) (Harahap 2018). Similarly, small and medium-sized furniture industries in urban and rural areas use a household-based system.

Business houses also known as home-based enterprises (HBE) are not something new in Indonesia or in other developing countries. This statement is in line with Kellett and Tipple (2000) research which stated that the use of home property to become HBE is very common. Basically, a house can be interpreted as the living place of an individual or family where daily activities are carried out as a process of selfdevelopment (Tutuko 2008). Furthermore, Newmark and Thompson (1977) defined a house as a place for humans (individuals or groups) to take refuge in carrying out their daily activities. Therefore, it can be concluded that the house is a place of residence, shelter and security for an individual or group to carry out their daily life activities. According to Silas (1993), the house functions not only as a place to live, take shelter, or rest, rather, it also acts as a place to raise residents' resources by determining the opportunities that exist to be more productive in opening a business (related to economic activities). Therefore, it can also be used as 
productive houses also known as home-based enterprises (HBE). This is also in line with Adianto and Gabe (2019) research which stated that HBE are basically inseparable from economic activities in an environment.

According to Strassmann (1986), home-based businesses in Indonesia have been around for decades with the aim of improving the people economy in urban and rural areas. Presently, this household-based business has become a necessity for communities to support their economy (Anderson 1982). Many Indonesians carry out non-formal businesses using part of their houses (Ernadia, Murtini, and Rukayah 2017).

According to Tipple (2005), economic or business functions are activities carried out by house owners, business workers and other people, such as selling or producing goods and services. Marsoyo and Astuti (2014) stated that householdbased business is the use of houses for microbusiness function spaces, which is run by one family. Therefore, based on the above meanings, it can be concluded that HBE are houses where part of the space is used for valuable economic activities that are jointly carried out jointly by one family. Household-based businesses, also known as HBE consist of two types of spatial functions, namely domestic and economic functions (Lirenzsa, Ellisa, and Paramitha 2020). A room with a domestic function is a primary need because it includes several activities and social interactions between home owners and other occupants. In general, a house functions as a domestic place before its transformation. This is different from the economic function space in a business house, which is the space used for producing and selling goods or services as a secondary function. Furthermore, the addition or utilization of space into economic activity or business in a house changes the spatial layout, which tends to later adjust the space requirements for commercial activities (Puspita and Rahmi 2019).

The phenomenon of changing a house from residential to business is rapidly growing in one of the villages in East Java, named Jorongan, Leces Subdistrict, Probolinggo Regency. Most of those living in Jorongan develop business functions in the furniture production sector. Its existence in this village was initially triggered by one of the people that started the business, which employed many local people. Over time, employees gained knowledge and experience in producing furniture and opened their own business opportunities in their houses. This process has continuously increased and sustained the furniture entrepreneurs in Jorongan Village till date. This can be proven from the research carried out by Jamaika, Subagirta, and Viphindrartin (2014) at Leces Subdistrict which shows that Jorongan Village is the largest furniture entrepreneur in Probolinggo Regency, with a total of 60 entrepreneurs. Therefore, the local government designated the village as the center for the furniture industry.

Some home-based businesses (UBR) changed some of their house functions to furniture business activities by utilizing part of their space or maximizing the remaining house land (Puspita and Rahmi 2019). This has the ability to change the spatial layout pattern, which varies from one business house to another (Taufikurrahman, Faqih, and Purnomo 2010). This research examines changes in the spatial layout at business houses caused by the furniture industry activity and determines the factors capable of affecting the spatial layout pattern of the furniture business house in Jorongan Village, Probolinggo Regency.

\section{Method}

This research was carried out in the Furniture Industry Center of Jorongan Village, Probolinggo Regency, which consists of 60 various types of furniture entrepreneurs. Data were purposively selected from 16 furniture entrepreneurs based on criteria related to the type of business, such as those carried out in houses, which is referred to as business houses and the land ownership status as shown in figure 1. 


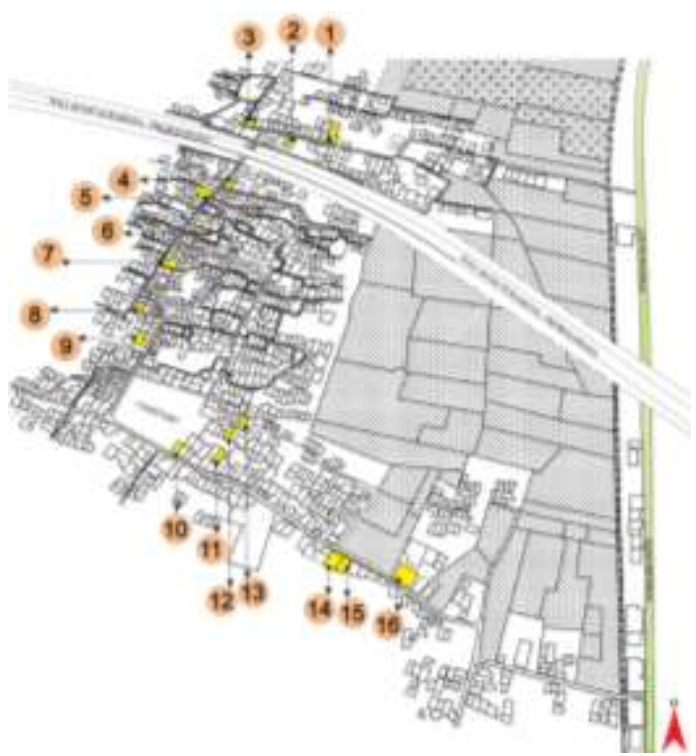

Figure 1. Location of the furniture business house in the furniture industry center at Jorongan Village, Probolinggo

This is a qualitative descriptive research, which describes the function and form of a furniture business house layout more accurately and systematically using empirical evidence (Amelia, Antariksa, and Suryasari 2015; Nugroho 2017). This research starts with the data collection stage through fielsd observations and interviews with the owners of each furniture business house. Field observations were carried out using a behavior mapping approach which aims to describe the activities of each user in utilizing the existing spatial functions. Furthermore, interviews with house owners were carried out with the aim of obtaining additional information regarding business houses (Fitria 2018; Ronarizkia and Yusran 2019).

Data and information were also obtained from previous research topics, which were used as support in determining the variables, such as the type, function and layout of the room. These variables are used in the analysis phase to reveal the layout pattern of a business house and the factors that influence the formation.

\section{Result and discussion}

Business house as a support to the economy

According to Silas (2000), a house that is partially used for business functions or economic activities (productive houses) can be divided into three types, namely

1. Separate type, is a house where business functions are more dominant than the primary residence needs. Sometimes, the residence function is placed at the back or front of the house in collaboration with the business space

2. Mixed type, is the function of a house as a residential and business area, although it is more dominant as a residence.

3. Balanced type has a clear separation between the house function as a residence and a business, despite being within the same scope. Taufikurrahman, Faqih, and Purnomo (2010) carried out a research that discusses types of productive houses in residential spatial patterns due to household-based industrial activities using metal craftsman houses in Ngingas Village, Waru, Sidoarjo Regency. This research showed that there are four types of productive houses based on spatial layout, as follows:

1. House with space for business and residential (household) functions.

2. House with a separate business space from outside the yard, which is still included in the territory of the house site.

3. House with business function space located in the front, side and back.

4. House with a business function space and a territorial barrier separating it from the residence area (household).

Based on the explanation above, these types of houses are used as the basis for identifying the location of the economic or business function room in Jorongan Village. This aims to determine the layout pattern of each business house as well as the factors that influence the formation of these spatial layout patterns.

Function and type of furniture business house

Based on the survey results, the furniture business houses in Jorongan village, Probolinggo Regency, are divided into two types, namely complex and craftsman. A house business complex is a mixed-use household with a production area (workplace) and a marketing (showroom). A craftsman's house is a mixture of household functions with a workplace.

1. Complex business house

A complex furniture entrepreneur carries out various stages of production, which starts from the initial to the final stage, namely marketing. This means that this type of furniture business has a more complete space than marketing 
(showroom) or production (workplace). There are eight complex business houses in the furniture industry center at Jorongan Village, Probolinggo Regency, as follows (table 1):

Table 1. Classification of complex furniture business houses in the furniture industry center of Probolinggo Regency

Floor plan

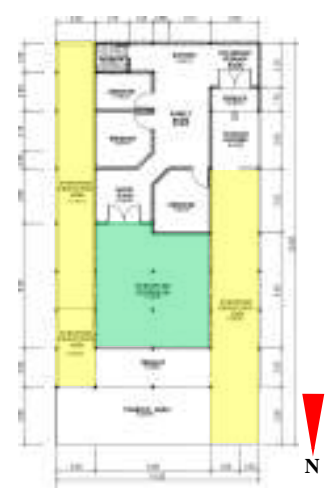

Mr. Hadi house (R2)

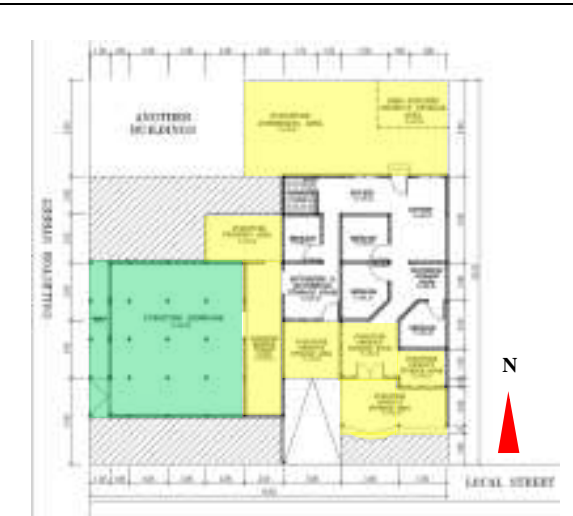

Mr. Kusbari house (R7)

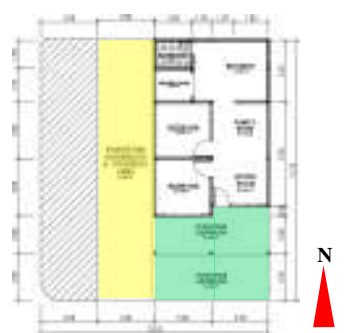

Mr. Sakur house (R8)

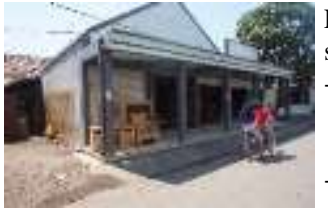

Economic areas are located at the front, back and side of the domestic function

- The front part is used as a storage space for furniture products, which are integrated into the main building

- The back is a space for the furniture production area to assemble and store frames

- The side of the house consists of a furniture production area, such as finishing, storage space and showroom

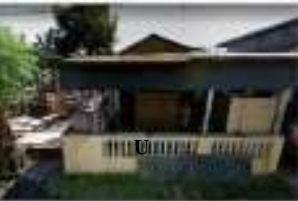

Economic function areas are located at the front and side of the main house.

- The front is used as a furniture showroom and it

is separated by doors and building walls

- The side is the furniture production area 

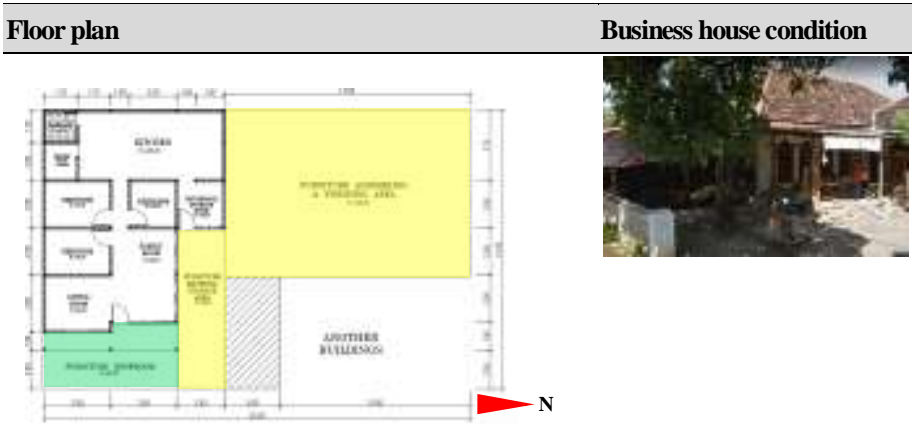

\section{Description}

Economic function areas are located at the front and side of the main house.

- The front is a furniture showroom separated by the door and the building wall

The side is a production storage room, assembly and finishing areas

Mr. Sholehusin house (R9)
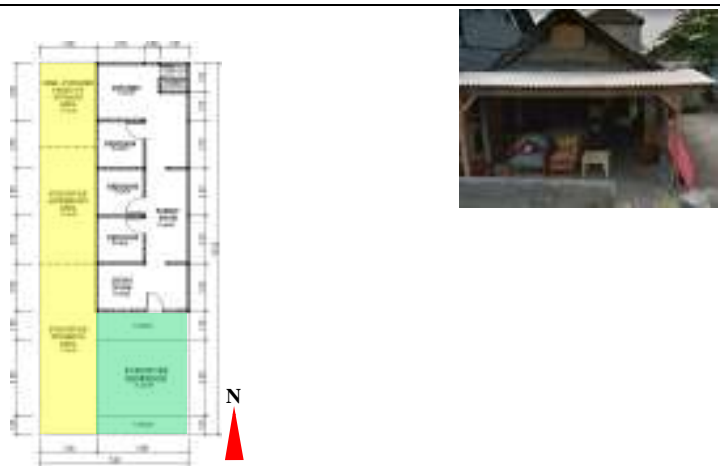

Economic function areas are located at the front and side of the main house.

- -The front is the furniture showroom area, separated by the door and the building wall - -The side part consists of the furniture production area, the finishing, assembly, frame and storage areas.

Mr. Mustofa house (R10)
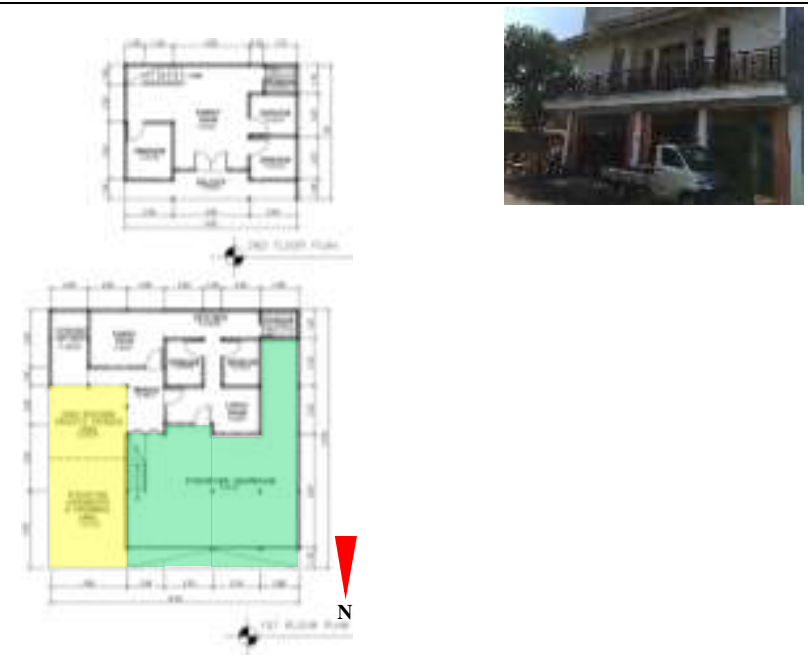

It consists of two floors, the domestic function area at the back of the second floor of the house, while the economy function area is on the first floor at the front and side of the main house.

- The front is the furniture showroom area, located within the same building

- The side part is a furniture production area which consists of an assembly room and a storage room for furniture frames

Mr. Sukarip house (R14) 


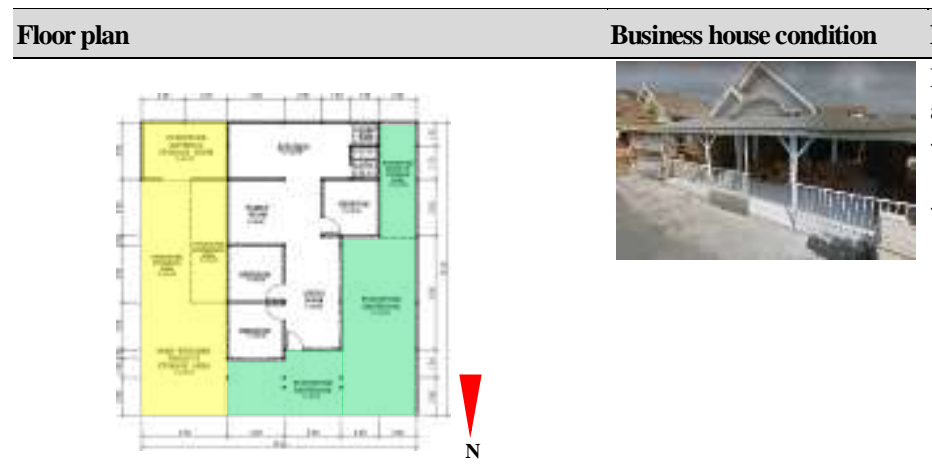

\author{
Description \\ Economic function areas are located at the front \\ and side of the main house. \\ - The front and west side is a furniture showroom \\ area \\ The east side is the furniture production area \\ (assembly, finishing and frame storage), while \\ the west side is part of the furniture showroom \\ space accompanied by a warehouse.
}

Mr. Syafi'i house (R15)
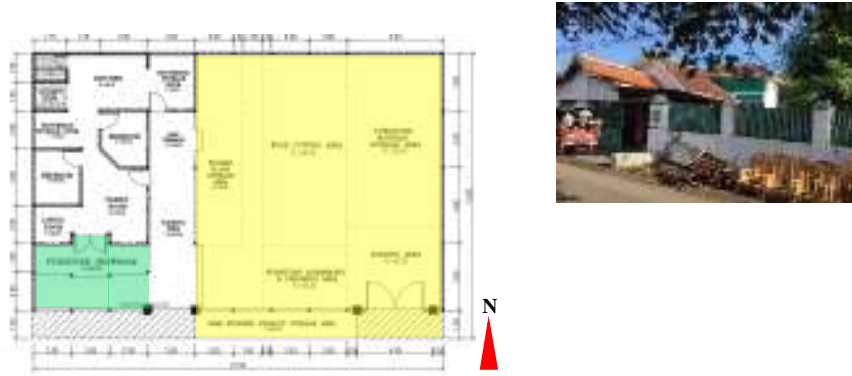

Economic function areas are located at the front and side of the main house.

- The front is a furniture showroom

- The side is a furniture production area consisting

of a storage room for raw materials, a wood scraps, a wood cutting room, an assembly and finishing room as well as a furniture logistics area

Mr. Suyanto house (R16)

2. Craftsman business house

A craftsman is a furniture entrepreneur that only carries out the production process at the workplace. The space in the production room is for storing materials, frames, assembling furnitures, and finishing areas. Table 2 provides a detailed a total of eight craftsman in the furniture industry center in Jorongan Village, Probolinggo Regency.

Table 2. Classification of craftsmen furniture business house in the furniture industry center at Probolinggo Regency
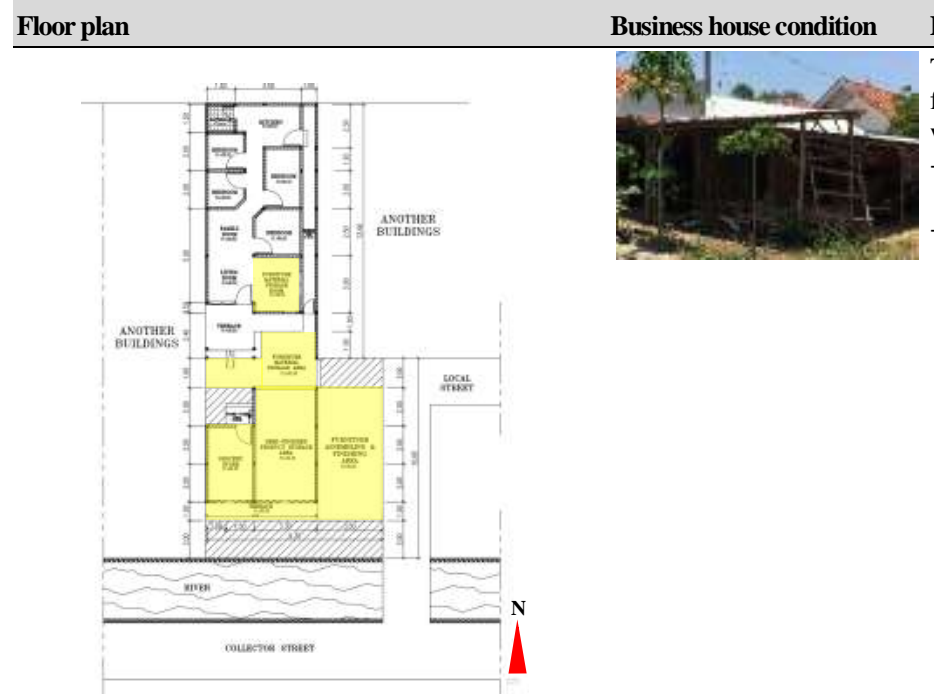

Description

The economic function area in the form of

furniture production space is located at the front, as

well as inside and outside the main house

- The front part of the main house is used for

storage space of furniture production materials

The outside of the main house is used for assembling and finishing rooms, as well as the furniture production warehouse located in a building different from the main house.

Mr. Jupri house (R1) 


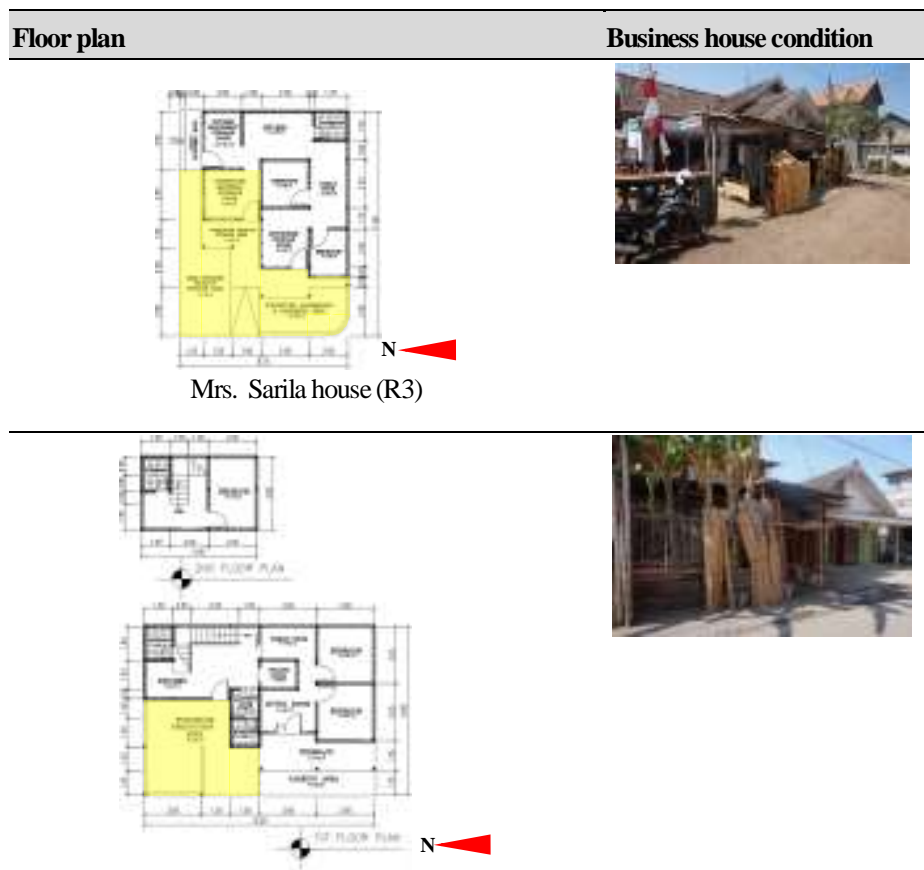

Description

The economic function area in the form of furniture production space is located inside and outside the main house

- The business function in the house is the storage room for furniture production materials.

- The business function on the front side is for assembling and finishing furniture, then on the side, it is used as storage space for storing products and frames.

Mr. Sarika house (R4)
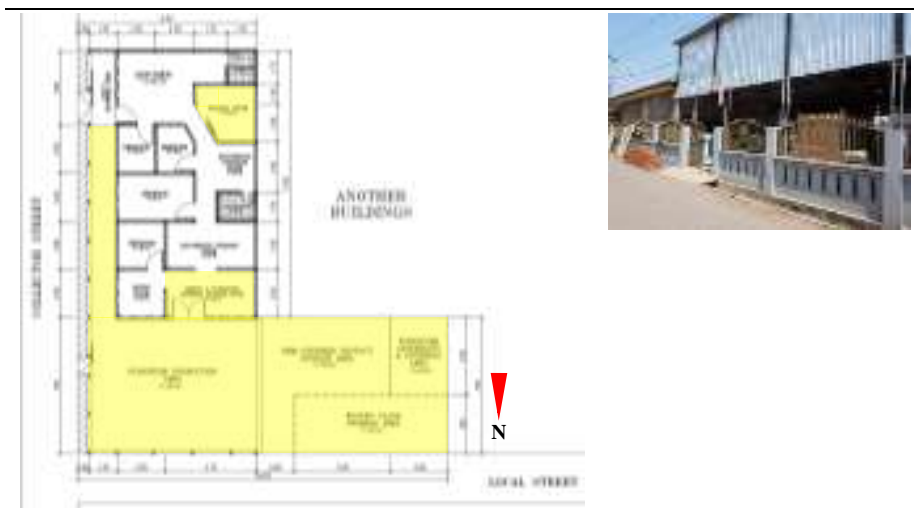

The economic function area in the form of a furniture production room located at the front and side of the main house, as well as inside and outside the building

- There are two furniture production rooms located inside the house, namely a kapok filling room and a sewing room, adjacent the domestic function and also used as a storage area for furniture products

- The front of the house is used for the furniture production area in general (sofas and wood materials), while the side production room is used for the assembly and finishing area for wooden furniture, storage space for frames as well as wood pieces.

Mr. Imam house (R5)
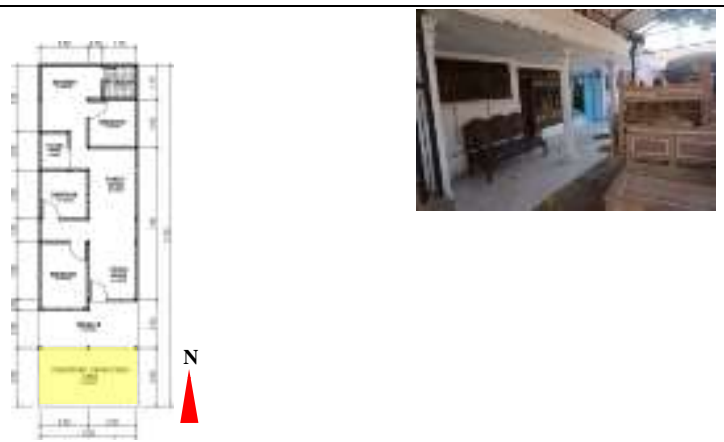

The economic function area in the form of a furniture production room is located at the front of the main building and used as a production room as well as storage of furniture frames and materials. It is located on the front porch

Mr. Abdul Wahid house (R6) 


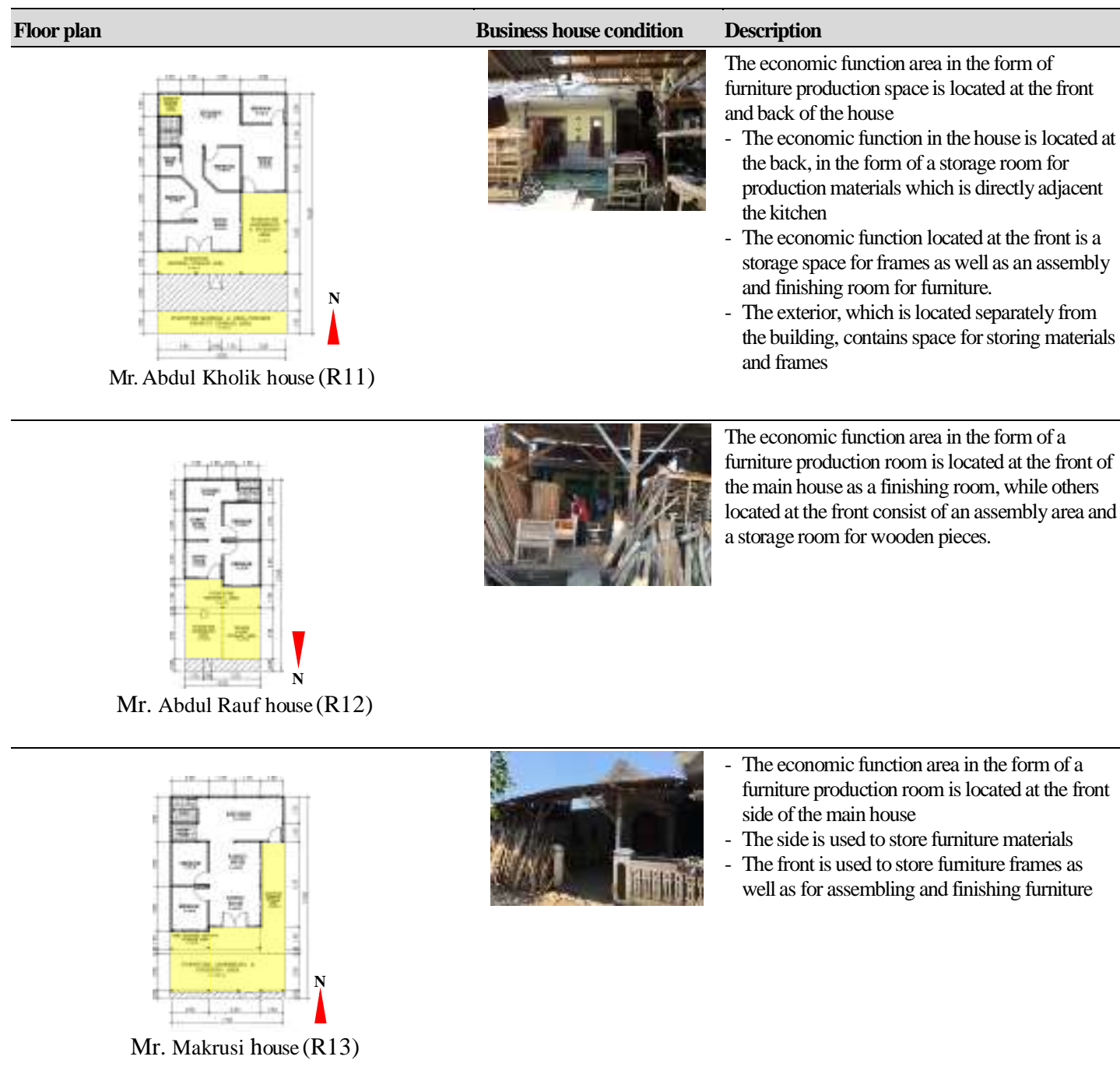

The layout of the furniture business room

Jorongan Village, which was originally a residential area recently become a furniture industry center with changes in the inner layout of the business house. The changes and layout of the furniture business function room have been previously described in Jorongan Village, Probolinggo Regency, in four types, namely:

1. The pattern of business function room, are partially inside, and beside the house (figure 2). 


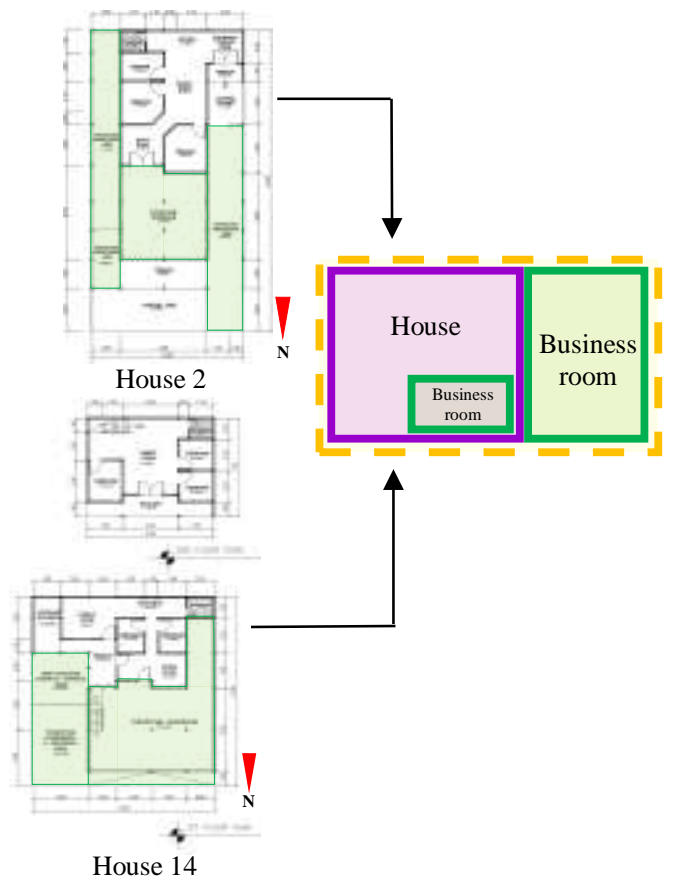

Figure 2. Classification of business houses pattern 1

The business houses in this pattern are entirely complex, consisting of the Mr. Hadi (R2) and Mr. Syafi'i (R14) houses. The economic or business function room placed on the side of the two houses is used as a furniture production room for assembling, finishing as well as storing the framework and materials. This is because the area for furniture production needs additional space that is wider and semi-open to fulfill several production processes that require sunlight and air for the drying process. Furthermore, the initial design of the two houses were on the left side of the land, therefore the furniture production room was placed in the side of the house.

In contrast to the economic or business function room on the inside of the building, these two houses function as a furniture showroom located at the front and visible direct from the road. These two business houses use the inner building for a furniture showroom because the products on display require protection and security from several things such as the weather in order to maintain its quality. Furthermore, the front position of the building is close to the road, therefore this furniture showroom is visible and reachable for visitors.

2. Business function space pattern, are partially inside buildings, and also located in front of and beside the house (figure 3 ).

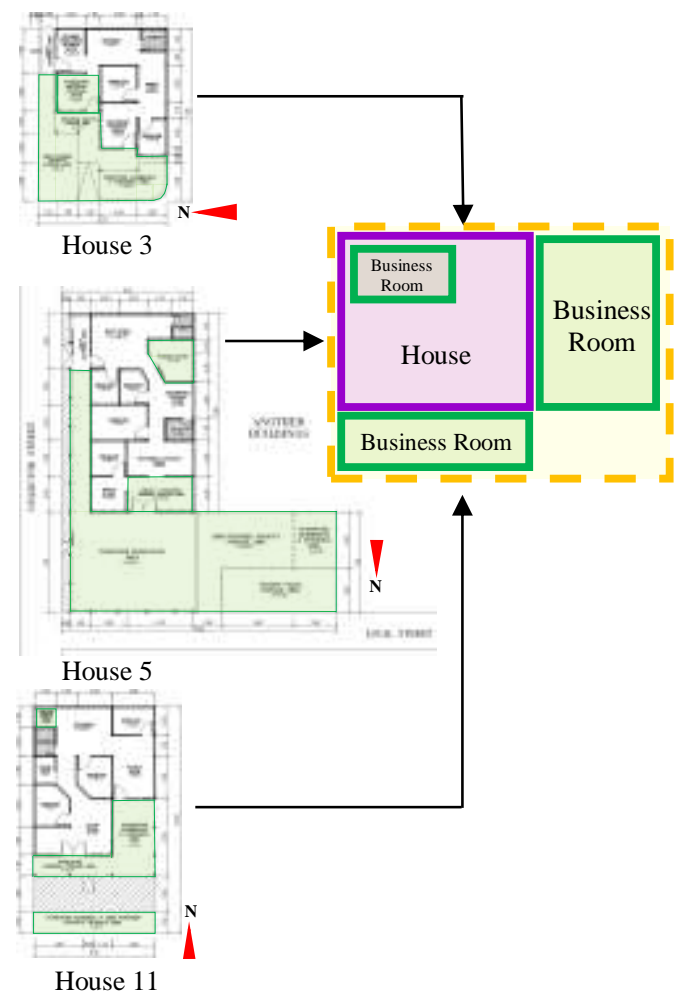

Figure 3. Classification of business houses pattern 2

The business house in this pattern is a type of craftsman furniture, which consists of houses belonging to Mrs. Sarila (R3), Mr. Imam (R5) and Mr. Abdul Kholik (R11). The business or economic function room placed on the side and front of the three houses is used as a furniture production room for assembling, finishing and storing the framework and materials. This is because the initial design of the three houses was at the left land on the sides and front of the house, therefore the furniture production room was located in that area. The business function room located at the front of the house certainly has an advantage in terms of marketing strategy because it is close to the road and can be seen more easily by visitors.

The location of the economic function room in the three houses is for storing materials and furniture production tools, except for Mr. Imam's house (R5) where it is used to store furniture production items, a sewing room and filling springbed cotton. Therefore, Mr. Imam's business house is the only furniture place that produces beds and springbeds. The location of this kapok filling room requires a closed space to maximize the filling process. Similarly, the storage room for furniture production is placed on the inside 
because there are certain materials such as sofa foam that need protection from outside conditions such as during rainfall.

3. The business function room pattern at the front of the house (figure 4).

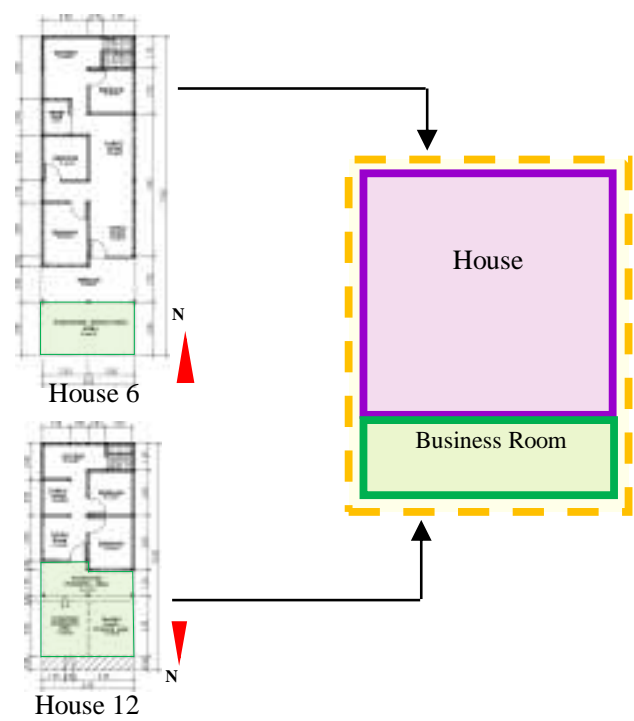

Figure 4. Classification of business houses pattern 3

The business houses included in this pattern are those of Mr. Abdul Wahid (R6) and Mr. Abdul Rauf (R12). The front space of the two houses are used as a room for assembling and finishing furniture as well as a space for storing materials and frames. This is because areas for assembling and finishing furniture need to be semi-open and exposed to sunlight or air for the drying process. The production room is also at the front because in the initial design the two houses only left the land in front of the house as a building border, therefore it is fully utilized for assembling, finishing and storing material as well as the front frame area which is the building boundary.

The production area is located close to the road, thereby making it easier for visitors to see, and providing an economic advantage. However, there are drawbacks in terms of accessibility which certainly interfere with guest or occupant access to the house.

4. The business function space pattern located at the front and side of the house (figure 5).

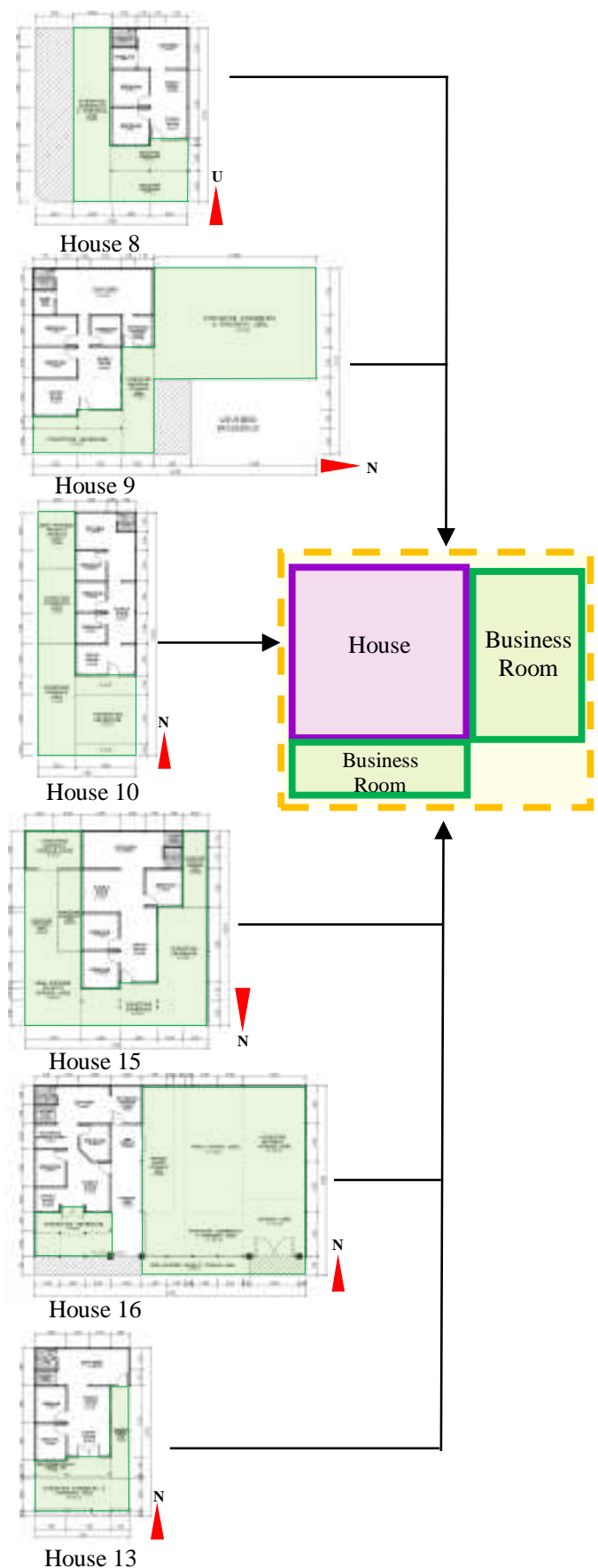

Figure 5. Classification of business houses pattern 4

Most of the business houses in this pattern are complex furniture with only one craftsman. The complex furniture business houses included in this pattern, are those of Mr. Sakur (R8), Mr. Sholehusin (R9), Mr. Mustofa (10), Mr. Syafi'i (R15) and Mr. Suyanto (R16). The fourth spatial 
layout pattern is Mr. Makrusi's (R13) business house.

It consists of a business function located at the front and side. The front part $\mathrm{o}$ is used as a furniture showroom function, which is a space to exhibit furniture products, therefore this area requires a space that is easily visible or accessible to visitors. The front area, adjacent to the road, has been chosen by many complex furniture business houses to place their furniture showrooms. Furthermore, the side area function as a furniture production area because the remaining land in the initial design, is close to the road. All types of complex business houses included in this pattern utilize the side area of the house from the back to the front which is directly adjacent to the road, therefore this production room can also be easily seen by visitors.

The houses pattern close to the road, especially the front, is certainly a strategic place in placing economic or business function spaces. Ronarizkia and Yusran (2019) while carrying out a research on a business house in Kampung Tridi Jodipan Malang, stated that all those in Tridi Village use the front area which originally functioned as a terrace for economic or businesses because it is directly adjacent to the main road of the tourist center, therefore easily visible and attract visitors to buy merchandise.

Finally, it was found that three houses had an irregular pattern due to their varying layouts, namely Mr. Jupri (R1), Mr. Sarika (R4) and Mr. Kusbari (R7).

Mr. Jupri's house is a type of craft with function rooms located on the inside and at the front. The front is used as a furniture assembly and finishing room, as well as a shop and furniture production warehouse. This is because the area for assembling and finishing furniture require a wider and semi-open area. Furthermore, the initial design of the two houses left some land in front of the house, which was used as the furniture production area. The business function space on the inside is a material storage space because it requires additional storage space for materials, such as sofa foam, which require protection from outside conditions (rainfall).

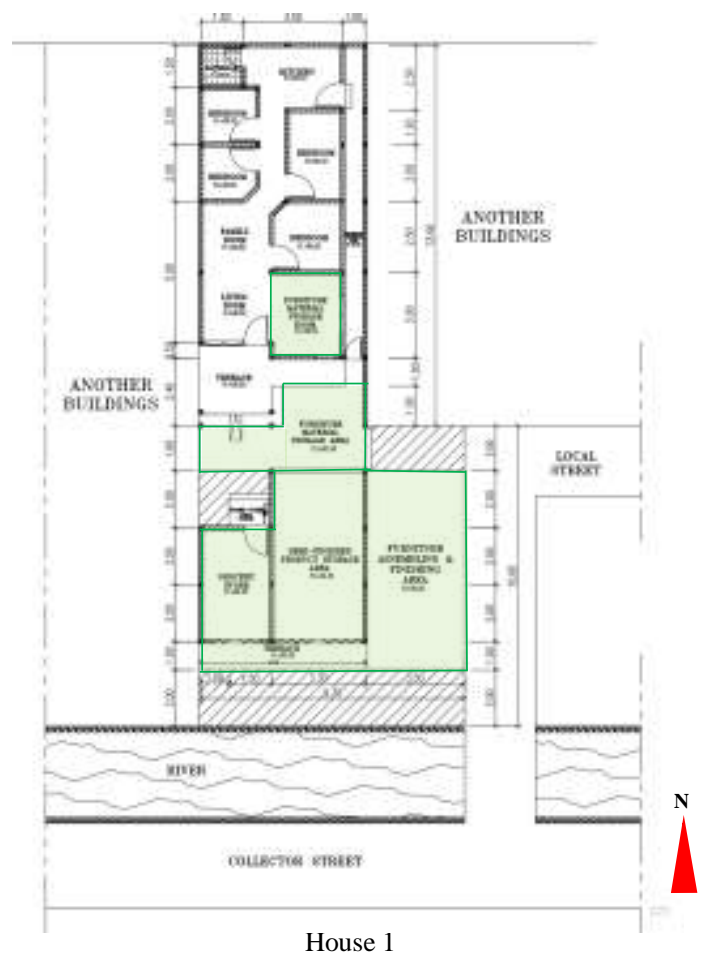

Figure 6. The layout pattern of Mr Jupri's house

Another furniture business house with a different pattern from others is owned by $\mathrm{Mr}$. Sarika (R4) with the function room located next to the house. This business house is a type of craftsman, with an economic function room located beside the building and used for assembling, finishing and storing furniture materials and frameworks. This is because in the initial design of the house only the left land beside owned by Mr. Sarika was limited. 


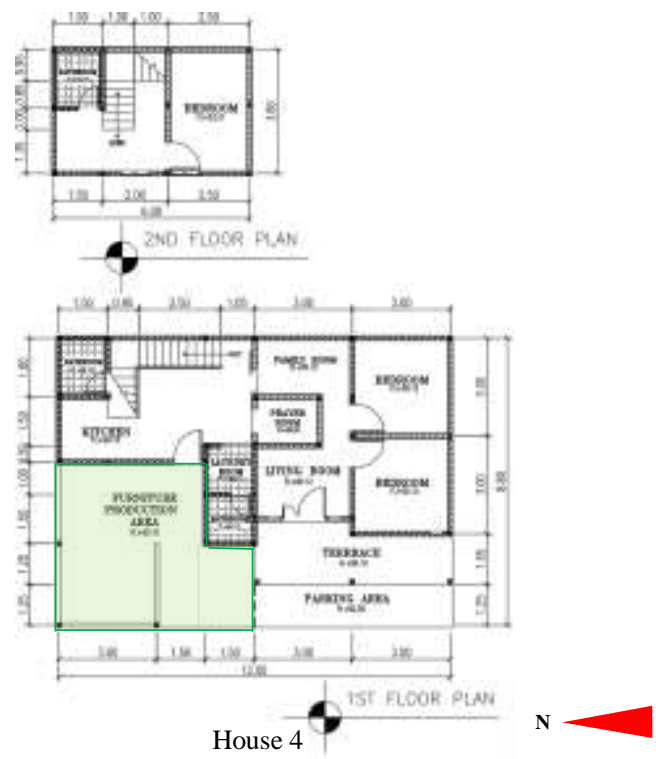

Figure 7. The layout pattern of Mr Sarika's house

Mr. Kusbari's (R7) house also has a different room layout pattern from others. This type of complex furniture business house has economic function rooms at the front, side and back. Furthermore, several business function rooms were also located on the inside of the main house. The back is fully used for furniture production, which consists of an assembly and a storage room. The front is used to place or store furniture products. Meanwhile, the side is used as the finishing room, material storage space and the furniture showroom. The furniture showroom is located next to Mr. Kusbari's house, which is close to the main road. Therefore, Mr. Kusbari prefers to build a different mass with the orientation facing the main road hence it is easier for visitors to visualize. The furniture business spatial layout in this business house is the main house surrounded by a business space, because the initial design consists of empty land on the front, side and back, therefore the main house is in the middle.

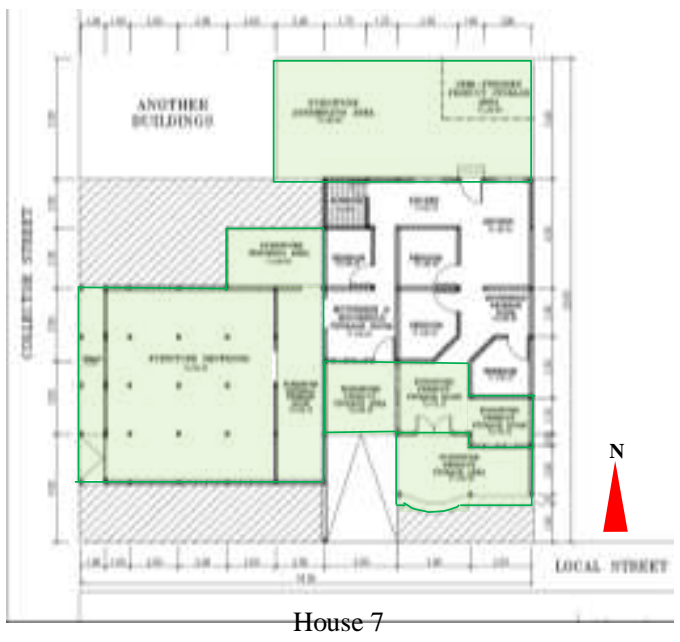

Figure 8. The layout pattern of Mr. Kusbari's business house

Factors that shape the layout pattern of the furniture business space

Based on the previous explanation regarding the layout pattern of the furniture business space, economic factors were found to shape the pattern in each house. This can be seen from the location of all furniture showrooms in the complex business house type of Jorongan Village, which is placed in front of the house. Therefore, it is directly adjacent to the main road in the Furniture Industry Center area of Probolinggo Regency. This area is widely used for business activities considered as the most strategic place to showcase furniture products, therefore, it is seen by visitors as potential buyers of furniture products.

This is also due to the ownership factor used in the production of equipment and land available in the initial design of each business house. The factor of equipment ownership can be viewed from the more complete equipment owned, the greater amount of land used for furniture production. A large production area requires a significant space and need to be placed on the outside. This is the same with Mr. Suyanto's (R14) business house, which has a wood cutting tool and a storage room for raw materials in the form of $\operatorname{logs}$, therefore the furniture production area is quite large and is placed on the outside of the building, even though it is still within the territory of Mr. Suyanto's house. This statement is similar to the research carried out by Taufikurrahman, Faqih, and Purnomo (2010) regarding changes in house space layout patterns due to metal industry activities in Ngingas Sidoarjo Village. The 
crosstab method that affect the spatial arrangement pattern formed in each business house are workers as space users, equipment ownership, house status, and income, while factors that do not affect changes are family structure, education, house design and age.

Furthermore, the land ownership factor of each previous house is influential. Business functions tend to be formed on previously remaining land because it functions as a secondary space, with its location adjusted to the the primary space of the previous domestic function.

\section{Conclusion}

The spatial layout pattern in the Furniture Industry Center of Probolinggo Regency consists of four patterns. Firstly, the type of business function space, located inside and outside the site territory. Secondly, the house with a business function space is on the front, side or back, and still directly adjacent to the house building. Thirdly, the types of business space, which are partly located in buildings, and on the front, side or back of the house. The pattern with the business function space is located at the front, side, as well as partially inside the building, while others are on the side, and then located inside buildings and partially located outside the front and side of the house.

Based on these four patterns, it is found that the most dominant pattern used in business houses in Jorongan Village, Probolinggo Regency is the fourth where the business function space is located at the front and side of the house. Most of the economic function rooms are located in an area directly adjacent to the main road of the Probolinggo Regency Furniture industry center area, which is the front of the house. Therefore, it is easier for visitors to see, and ease to market the furniture products. Furthermore, most house owners only use the remaining existing land without buying additional land because the facilities or equipment owned by majority of the furniture business houses in this village are also minimal. These two things illustrate that economic factors and ownership of production equipment as well as land ownership are factors that influence the shape of the business houses layout pattern in the Furniture Industry Center, Jorongan Village, Probolinggo Regency.

\section{References}

Adianto, Joko, and Rossa Turpuk Gabe. 2019. 'The Spatial Strategies and Its Mechanism of Home-Based Enterprise in Kampong Cikini, Jakarta'. A/Z: ITU Journal of Faculty of Architecture $16 \quad$ (2): 55-68. https://doi.org/10.5505/itujfa.2019.65668.

Amelia, Rizky, Antariksa, and Noviani Suryasari. 2015. 'Tata Letak Ruang Hunian-Usaha Pada Rumah Lama Milik Pengusaha Batik Kalangbret Tulungagung'. Jurnal Mahasiswa $\begin{array}{llll}\text { Jurusan } & \text { Arsitektur } & 3 & \text { (2). }\end{array}$ http://arsitektur.studentjournal.ub.ac.id/index. php/jma/article/view/110/107.

Anderson, Dennis. 1982. 'Small Industry in Developing Countries: A Discussion of Issues'. World Development 10 (11): 913-48. https://doi.org/10.1016/0305750X(82)90034-1.

Ernadia, Loretta, Titin Woro Murtini, and R. Siti Rukayah. 2017. 'Perubahan Lingkungan Dan Tata Ruang Rumah Tinggal Di Desa Wisata Kandri'. Tesa Arsitektur 15 (1): 41-53. http://journal.unika.ac.id/index.php/tesa/articl e/view/1006.

Fitria, Tika Ainunnisa. 2018. 'Pengaruh Seting Ruang Terhadap Perilaku Pengguna Dengan Pendekatan Behavioral Mapping'. Jurnal Arsitektur Dan Perencanaan (JUARA) 1 (2): 183-206.

https://ejournal.unisayogya.ac.id/ejournal/ind ex.php/JUARA/article/view/775/pdf.

Harahap, Azwar. 2018. 'Analysis Of Micro And Small Industry Development In Indonesia'. International Journal of Scientific \& $\begin{array}{llll}\text { Technology } & \text { Research } & 7 & \text { (4). }\end{array}$ https://www.ijstr.org/finalprint/apr2018/Analysis-Of-Micro-AndSmall-Industry-Development-InIndonesia.pdf.

Jamaika, Putri, I Wayan Subagirta, and Sebastiana Viphindrartin. 2014. 'Analisis Faktor Yang Mempengaruhi Pendapatan Pengusaha Mebel Di Kecamatan Leces Kabupaten Probolinggo'. Artikel Ilmiah Mahasiswa, 1-6. http://repository.unej.ac.id/bitstream/handle/1 23456789/64386/Putri Jamaika.pdf?sequence $=1 \&$ isAllowed $=y$.

Kellett, Peter, and A Graham Tipple. 2000. 'The Home as Workplace: A Study of IncomeGenerating Activities within the Domestic 
Setting'. Environment and Urbanization 12 (1):

203-14. https://doi.org/10.1177/09562478000120011 5.

Lestari, Etty Puji. 2010. 'Penguatan Ekonomi Industri Kecil Dan Menengah Melalui Platform Klaster Industri'. Jurnal Organisasi Dan Manajemen 6 (2): 146-57. https://jurnal.ut.ac.id/index.php/jom/article/vi ew/289.

Lirenzsa, F, E Ellisa, and A Paramitha. 2020. 'Spatial Negotiations in Domestic Space of the Home-Based Garment Industry in Kampung Tambora, Jakarta'. IOP Conference Series: Earth and Environmental Science 447 (March):

012032. https://doi.org/10.1088/17551315/447/1/012032.

Marsoyo, Agam, and Wahyu Kusuma Astuti. 2014. 'The Prospect of Poor Home-Based Enterprises in Yogyakarta'. In Space for the Next Generation. 2nd ICIAP. https://silo.tips/download/the-prospect-ofpoor-home-based-enterprises-in-yogyakarta.

Newmark, Norma L., and Patricia J. Thompson. 1977. Self, Space, and Shelter: An Introduction to Housing. New York: Harper and Row Publizer Inc.

Nugroho, Rahadian. 2017. 'Pengaruh Kearifan Budaya Lokal Terhadap Hunian Masyarakat Pengrajin Tempe Di Kampung Sanan Malang'. Local Wisdom: Jurnal Ilmiah Kajian Kearifan Lokal 9 https://doi.org/10.26905/lw.v9i2.1978.

Puspita, Luluk Rani, and Dwita Hadi Rahmi. 2019. 'Horizontal Spatial Transformation of Home-Based Enterprises in Kampung Karangasem, Depok, Sleman'. Journal of Architectural Research and Design Studies 2 (2). https://doi.org/10.20885/jars.vol2.iss2.art7.

Ronarizkia, Adita, and Yusfan Adeputera Yusran. 2019. 'Utilization Pattern Of Residential Terrace as a Trading'. DIMENSI (Journal of Architecture and Built Environment) 46 (1):
51-58. https://doi.org/10.9744/dimensi.46.1.51-58.

Silas, Johan. 1993. Housing Beyond Home; Case Study of Surabaya. Surabaya: ITS.

2000. 'Rumah Produktif Pendekatan Tradisi Dan Masyarakat'. Surabaya.

Siswaningsih, Dwi. 2016. 'Kinerja Ekspor Indonesia 2016'. Warta Ekspor, December 2016.

http://djpen.kemendag.go.id/app_frontend/ad min/docs/publication/8331514958117.pdf.

Strassmann, W. Paul. 1986. 'Types of Neighbourhood and Home-Based Enterprises: Evidence from Lima, Peru'. Urban Studies 23 (6): 485-500. https://doi.org/10.1080/00420988620080781.

Taufikurrahman, Muhammad Faqih, and Hari Purnomo. 2010. 'Perubahan Pola Tatanan Ruang Rumah Tinggal Sebagai Akibat Kegiatan Industri Rumah Tangga'. In Perumahan Permukiman Dalam Pembangunan Kota. Surabaya: ITS. https://pdfslide.tips/documents/perubahanpola-tatanan-ruang-rumah-tinggal-sebagaiakibat-secara-fisik-dan-non.html.

Tipple, Graham. 2005. 'The Place of HomeBased Enterprises in the Informal Sector: Evidence from Cochabamba, New Delhi, Surabaya and Pretoria'. Urban Studies 42 (4): 611-32. https://doi.org/10.1080/00420980500060178.

Tutuko, Pindo. 2008. Permukiman Rumah Produktif Dan Perkembangannya. Malang: GKAK Arsitektur Universitas Merdeka Malang.

\section{Author(s) contribution}

Adita Ronarizkia contributed to the research concepts preparation, methodologies, investigations, data analysis, visualization, articles drafting and revisions.

Lisa Dwi Wulandari contribute to the research concepts preparation and literature reviews, data analysis, of article drafts preparation and validation.

Yusfan Adeputera Yusran contribute to methodology, supervision, and validation. 